\title{
Olives and olive oil production in the Alto Ricaurte climate region in Boyaca, Colombia
}

\section{Producción de aceitunas y aceite de oliva en el clima de la región del alto Ricaurte en Boyacá Colombia}
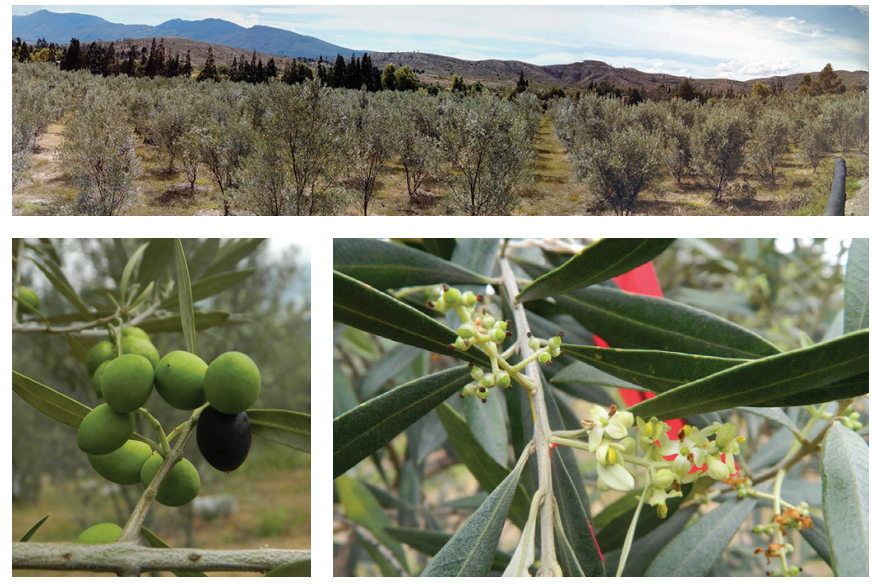

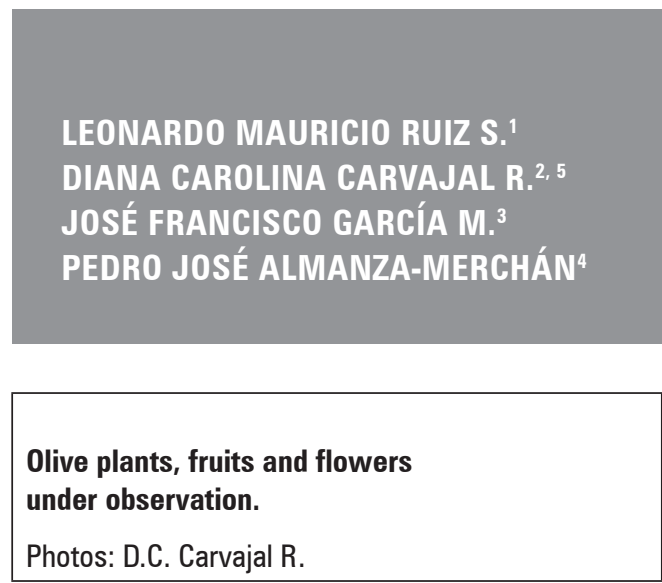

\section{ABSTRACT}

The olive tree has expanded to several countries because of its easy adaptation to difficult edapho-climatic zones and high culinary and medicinal interest given the physicochemical composition of its fruit, including Argentina, Chile, Peru and Mexico, which have similar soil and climate conditions to the Mediterranean, where the phenological stages correspond to clearly distinct climatic seasons. However, in the Alto Ricaurte region in Boyaca, Colombia, olives do not set because of the tropical climate conditions. Because of these characteristics, the behavior of some trees, sown 4 to 30 years ago in this region, were evaluated. The temperature and precipitation were measured, and 20 branches were selected per tree, which were monitored from appearance until development; the polar and equatorial diameter of the fruits were measured until reaching maturation. A fruit and oil analysis was carried out with olives harvested in two maturation states in 2017. The temperature had a positive correlation with the phenological stages in a range of 11 to $29^{\circ} \mathrm{C}$, which directly influenced the development of inflorescences and their performance. In the same year, there were two or more blooms with different intervals, where the same branch had inflorescences, flowers, freshly filled fruits and other mature fruits. As for the characteristics of the fruit and the oil, it was evident that the content of fatty acids was within the parameters required by the International Olive Council.

Additional key words: sprouting and flowering; physiological maturity; fatty acids; olive oil.

Universidad Pedagógica y Tecnológica de Colombia (UPTC), Tunja (Colombia). ORCID Ruiz S., L.M.: 0000-0002-0902-5605

2 Fundación Universitaria Juan de Castellanos, Research Group AOF, Tunja (Colombia). ORCID Carvajal R., D.C.: 0000-0001-8890-3746

3 Università degli studi di Parma, Research Group AOF, Tunja (Colombia). ORCID Garcia M., J.F.: 0000-0003-3767-6197

4 Universidad Pedagogica y Tecnologica de Colombia (UPTC), Faculy of Agricultural Sciences, Research Group on Sustainable Agricultural Development and Production (GIPSO), Tunja (Colombia).ORCID Almanza-Merchán, P.J.: 0000-0002-9207-0617

5 Corresponding author.dcarvajal@jdc.edu.co 


\section{RESUMEN}

El olivo por su fácil adaptación a zonas edafoclimáticas difíciles, así como por el interés gastronómico, medicinal, y dada la composición bromatológica del fruto, se expandió por diferentes países como Argentina, Chile, Perú y México, que tienen condiciones de suelo y clima similares al Mediterráneo, donde sus estados fenológicos coinciden con las estaciones climáticas que son bien marcadas, a diferencia de lo que ocurre en el Alto Ricaurte Boyacá -Colombia, que por las condiciones del clima tropical, no le permiten estacionarse. Debido a estas características se evaluó el comportamiento de árboles de 4 y 30 años sembrados en esta región, donde se midió la temperatura y precipitación además de seleccionar 20 ramas por árbol, a las que se le hizo seguimiento desde el momento de la emergencia hasta su desarrollo; a los frutos se les midió el diámetro polar y ecuatorial hasta llegar a maduración, en cuento a los análisis de frutos y aceite se hizo una comparación con aceitunas cosechadas en dos estados de maduración y aceite del 2017. Arrojando como resultado que la temperatura tiene una correlación positiva sobre los estados fenológicos ya que a rangos de 11 y $29^{\circ} \mathrm{C}$ influyen directamente en el desarrollo de las inflorescencias y su comportamiento, además durante el año se presentan dos o más floraciones con intervalos de tiempo diverso donde se observó que en la misma rama existían inflorescencias, flores, frutos recién cuajados y otros maduros. En cuanto a las características del fruto y el aceite se evidencia que el contenido de ácidos grasos se encuentra dentro de los parámetros exigidos por el Consejo Oleícola Internacional (COI).

Palabras clave adicionales: brotación y floración; envero; madurez fisiológica; ácidos grasos; aceite.

Received for publication: 09-04-2018 Accepted for publication: 29-03-2019

INTRODUCTION

The olive tree (Olea europaea L.) is an evergreen tree that belongs to the species Olea, which has 35 species, and the Oleaceae family. It has a unique edible fruit (Kostelos and Kiritsakis, 2017). In addition, it has had gastronomic and medicinal interest since the fourth millennium before Christ. It has been used for food, cosmetics, medicines and symbols because of its physicochemical, nutraceutical, pharmaceutical and chemical characteristics (Martínez et al., 2014). Furthermore, its demand is based on positive effects on human health, specifically its high content of natural antioxidants and monounsaturated fatty acids (Bahloul et al., 2014).

Studies on the different phonological phases, reproductive blossom, morphology, physiology and flowering stage, influenced by meteorological variables (temperature, radiation, precipitation) that affect induction, differentiation and flowering, have demonstrated that these aspects directly determine the number of fruits that can be harvested (Rojo and Pérez-Badia, 2014). As a result, sprouting and flowering can be carried out between late winter and early spring with axillary buds that have a small structure and whose presence in leaves varies according to the leaf type and stage of charge (Sotomayor, 2002).
The importance of the accessory buds is based on the growth of new leaves on laden trees because the construction and rise of foliar mass increase possible potential sites for the formation of the next inflorescences (Castillo-Llanque and Rapoport, 2011; Carvajal-R. et al., 2018).

As a consequence, in order for the tree to grow in marginal situations, resist climate changes and adapt to modern agronomic techniques of pruning, it needs this type of buds, as seen in Peru (Tonconi, 2014). However, in Colombia, a study has not been reported because the High Ricaurte province in Boyaca is a unique zone with productive advantages (GarcíaMolano, 2010). According to García-Molano et al., 2012, the Olive tree in Colombia has difficulties because the seasonal differentiation during the year is not adequate. There is not an accumulation of cold hours for floral induction, with average temperatures of $26^{\circ} \mathrm{C}$ in the day and $7^{\circ} \mathrm{C}$ at night; the photoperiod is almost constant during the year, which does not provide the plant a repose period because the photosynthetic activity is permanent (García-Molano and Jaramillo, 2012). Also, it has been found that floral differentiation happens through hydric stress (García-Molano and Cheverria, 2014). 
On the one hand, this situation influences the flowering process throughout the year, which appears in the different phenological stages (García-Molano, 2012). The fruit quality and quantity are affected because the vegetative and reproductive growth happen at the same time. This simultaneity provokes a series of interactions between sinks (leaves, fruits, and buds) that affects the fruiting tree during its productive cycle (Castillo-Llanque and Rapoport, 2011). According to Rapoport and Moreno-Alías (2017), in olive producing regions, inflorescences are developed in the foliar axils of vegetative growth, and the knots from previous year to the flowering between July and October usually appear on the wood from last year and, in some varieties, appear over the wood from 2 years prior; while, in the Alto Ricaurte region, this situation does not occur.

On the other hand, in this region, the plants do not have the pruning management used in producing zones, where, once the harvest is finished, the plants are pruned to achieve a balance between the vegetative and reproductive cycle because of the physiological performance of the plants (Medina and Perdomo, 2015; Pérez, 2017). For instance, in Argentina, the harvest usually last over 5 months, starting in February on the table olive plantations and continuing until June and July on the olive oil plantations (Gómez del Campo et al., 2010). However, in Mexico, the harvest starts in August and ends in November, depending on the variety (Grijalva et al., 2014); while, in Chile, the harvest is between middle April and middle June, depending on the variety and the zone, and, in Peru, $97 \%$ of the production is done between April and July, and, from the end of February to April, green olives are collected, and Black Olives are picked between May and July (Cazanga et al., 2013).

The harvest is picked in just one period, depending on the seasons, but this does not happen in the high Andean tropics. In addition, in temperate regions, floral induction in olive trees arises in the previous summer, with temperatures between 25 and $40^{\circ} \mathrm{C}$ on average, and floral initiation occurs in autumn; then, in winter, the plant gets rest, where the temperature falls below $0^{\circ} \mathrm{C}$, and, in spring, the plant is activated physiologically with temperatures between 25 and $20^{\circ} \mathrm{C}$ (Cazanga et al., 2013, Torres et al., 2017, Rallo and Cuevas, 2017), which confirms that induction and floral differentiation in Olive producing areas are determined by thermic stress; while, in the tropics, floral induction is unknown, but floral differentiation happens through hydric stress according to GarcíaMolano and Jaramillo (2012).

For these reasons, this article intends to distinguish the factors that theoretically define the optimal point of harvest, as well as, the effect of pruning on the physical-chemical characteristics of the fruits and physiological maturity in the Alto Ricaurte region, using the climatic conditions of olive-producing regions in the world as a reference.

\section{MATERIALS AND METHODS}

Boyaca is located at $04^{\circ} 39^{\prime} 10^{\prime \prime}$ and $07^{\circ} 03^{\prime} 17^{\prime \prime}$ north latitude and $71^{\circ} 57$ ' $49^{\circ}$ " and $74^{\circ} 41^{\prime}$ ' 35" west longitude, in the middle of eastern Colombia. The region of Alto Ricaurte contains the villages Villa de Leyva, Sutamarchan, Tinjaca, Sachica and Raquira, which are located in the center of the department at a height of $2200 \mathrm{~m}$ asl on average, and the temperature is $18^{\circ} \mathrm{C}$, with an overnight temperature of $5.7^{\circ} \mathrm{C}$. There are also hot and dry days with an average temperature of $27^{\circ} \mathrm{C}$. Moreover, the rainfall is on average $993 \mathrm{~mm}$, and there are strong winds in the months of July and August; the annual sun intensity is about $1869 \mathrm{~h}$, the relative humidity is $75 \%$, and the cloudiness is six octas according to the reports of the Institute of Meteorology and Land Adaptation IDEAM.

Firstly, the data stated in this article correspond to research carried out on olive trees planted in the region of the Alto Ricaurte 4 to 30 years ago. The measurable variables were temperature and precipitation from 2009 and 2014. This information was collected from the IDEAM Tintales weather station, using the monthly average. Secondly, in 2016 and 2017, a dataloger Exteeh-RHT20 (Extech Instruments, Waltham, MA) was installed in Huerto Olivato, which obtained the data of temperature and relative humidity. A rain measurement instrument recorded data for daily precipitation, which was measured to get the annual rate. In addition, 20 trees were selected to acquire the inflorescence length, the number of flowers and the fruit growth. 20 branches of each one were also selected, which were tracked from sprouting until development and fructification; length, number of flowers and fruits were studied.

According to the process, in step one, the fruits were measured; their polar and equatorial diameters throughout growth until maturity were analyzed. In step two, the fatty acids in the leaf were selected, 300 
$\mathrm{g}$ from the canopy of each one of the trees, 4 and 3 years old. Likewise, the fruits and oil were compared with olives harvested in two maturity and oil stages in 2017; moreover, the leaves, fruits and oil were processed in a laboratory of the interdisciplinary research group of molecular studies from the Universidad de Antioquia, which were analyzed and interpreted.

\section{RESULTS AND DISCUSSIONS}

\section{Flowering}

The vegetative and reproductive growth of leaves, as well as, the development of fruits, are a cyclical phenomenon, both are repeated year after year. The processes that lead to fructification need two consecutive seasons, while leaf growth is completed in one year. Bud formation, floral induction and rest take place in the first season. Inflorescences, flowering, and fruit growth and development take place in the second season and conclude at maturity (Oteros et al., 2013; Trentacoste et al., 2017); however, according to the region studied, flowering usually appears in the branches that are growing, but not in those that grew the previous year; that is why the biennial cycle does not occur; additionally, there is evidence that trees can have two or more flowerings and harvests, depending on the precipitation (García-Molano et al., 2012).

On the other hand, in traditional olive-growing regions, winter temperature influences the flowering rate of the next season because trees are not fruitful unless they are exposed to a certain cold temperature; therefore, winter cold is the natural factor that provides the repose period to floral buds (Urbina, 2015); at the same time, dry and warm winds during the flowering period are associated with a reduction in fruit setting because the stigma is dried off, and the pollen is dehydrated (Bueno and Oviedo, 2014). Nevertheless, in the studied region, the trees were not influenced in this way because, according to the IDEAM, (2012) the temperature oscillates between 25.2 and $29.9^{\circ} \mathrm{C}$ throughout the day, with an average of $27.6^{\circ} \mathrm{C}$, and between 6.21 and $12.3^{\circ} \mathrm{C}$ at night, with an average of $9.51^{\circ} \mathrm{C}$ (Fig. 1). Subsequently, there is not accumulation of cold hours, which determine flowering; Furthermore, the $68 \%$ relative humidity maintained pollen feasibility. This condition is an advantage because the stigma is receptive, and it helps pollination; as a consequence, harvests are matched with higher precipitation years.

\section{Inflorescence}

Temperature is the main factor, which allows the development of the Inflorescences, $72^{\circ} \mathrm{C}$ are required in the months of April and May to induce Inflorescence, as well as, a long exposure to cold for the optimum level of floral buds. Also, there is a dependent effect of the genotype (Rapoport, 2014; Carvajal-R. et al., 2018). Latitude does not have any effect on the induction of floral buds (Breton and Berville, 2013). The most fruitful buds are in

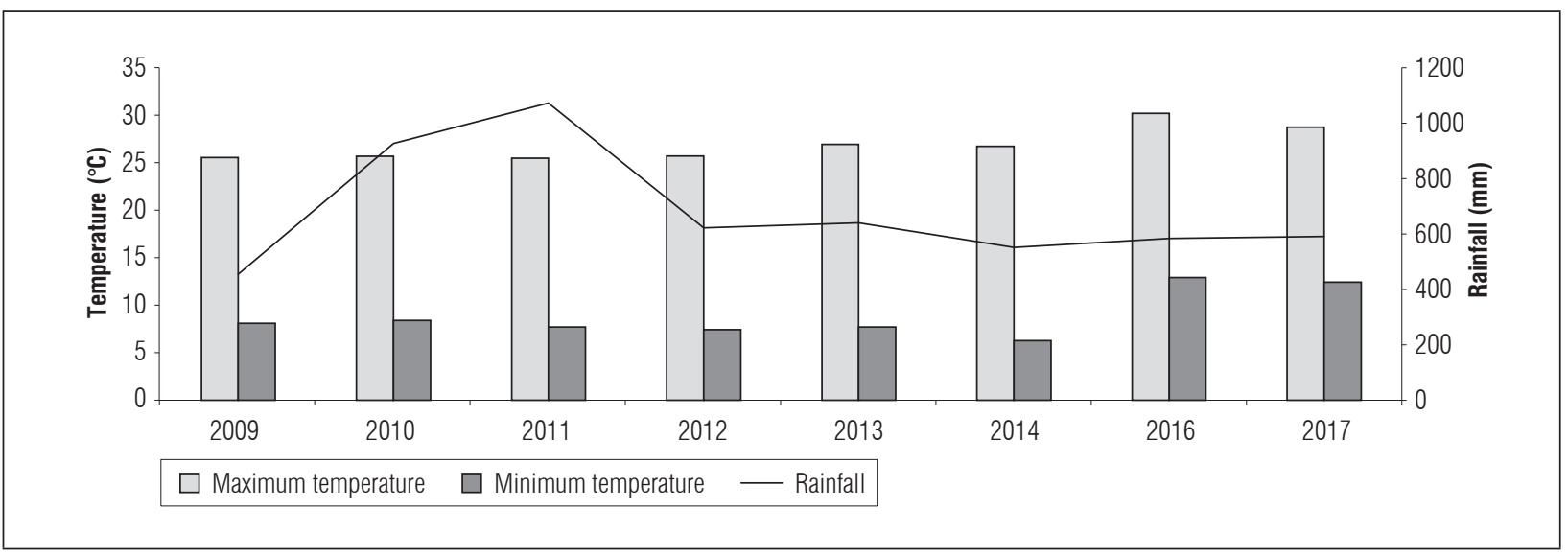

Figure 1. Performance of the average temperature and precipitation from 2009 until 2014 and from 2016 to 2017 in Alto Ricaurte (Colombia), with a $27.6^{\circ} \mathrm{C}$ average temperature and an average temperature of $9.51^{\circ} \mathrm{C}$ during the night. The higher observed precipitations were $918.9 \mathrm{~mm}$ in 2010 and $1063.73 \mathrm{~mm}$ in 2011, and the lowest value was $450.4 \mathrm{~mm}$ in 2009, followed by $546.4 \mathrm{~mm}$ in 2014 
the central area of the branch; nevertheless, in the tropics, this is not its performance, because, there is a pattern, to bloom in new branches according to García-Molano et al. (2012).

Summer in the Northern and Southern Hemispheres does not have an observable effect on olives; nevertheless, it has been discovered along the study, and this effect is the floral induction phenomenon, that means the heat and the drought produce on the tree a series of chemical incentives, which are convenient for the tree. This is why, the next year will again produce plentiful flowering, as a result, the olive tree does not adapt to humid climates (Marcos, 2012).

The floral beginning includes two processes: the first one is bud predisposition to developing floral structures in the next year because of a hormonal stimulus in the induction moment, generated by the presence of fruits that have grown in the branch the previous year. This situation was not clear in the Alto Ricaurte region because the fruits grew in emerging branches. The second one is differentiation of the inflorescence and flower structures, which happens in the next year's spring in the branch that grew the previous year (Rojo and Pérez-Badia, 2014). Nonetheless, in the tropics, floral differentiation happens when precipitation starts, as was observed in the years 2001 and 2007 (García-Molano and Jaramillo, 2012). Similarly, it has been observed that olives trees have not grown because of the "El Niño" phenomenon, which happened in 2009 with longs periods of drought and rainfall of about $872.3 \mathrm{~mm}$ (IDEAM, 2009).

The trees stopped growth, and the apical meristems were dehydrated, which demonstrated that the olives were set, but, then in the winter of 2010 - 2011 with rainfall of $1546-1732 \mathrm{~mm}$, the olive trees again began the vegetative growth, followed by flowering that would have become fruits if the winter lasted at least two months, coinciding with the study by Tapia (2012).

The floral structure called "Miñolatura" is green at first and then becomes white because of the presence of petals, with a central axis (raquis) and diverse ramifications where several flowers are located that measure between 10 and $70 \mathrm{~mm}$ and contain between 10 and 40 flowers. The inserted inflorescences in the proximal and distal sides of the branches have smaller dimensions (Toscano et al., 2015). The floral structure in the Alto Ricaurte was between 22 and $66 \mathrm{~mm}$ and contained between 20 and 27 flowers on average (Fig. 2). Also, the floral structure changed intensity among the varieties, tree ages, and times that tree bloomed during the year because the bloom appeared two or more times, with intervals between 6 and 8 weeks with respect to the beginning of the process (Fig. 2). This situation was observed in the years 2010 and 2011 because of rainfall in both years, as observed by (Torres et al., 2017), who worked with flowering, water requirements and olive oil quality as responses to new crops.

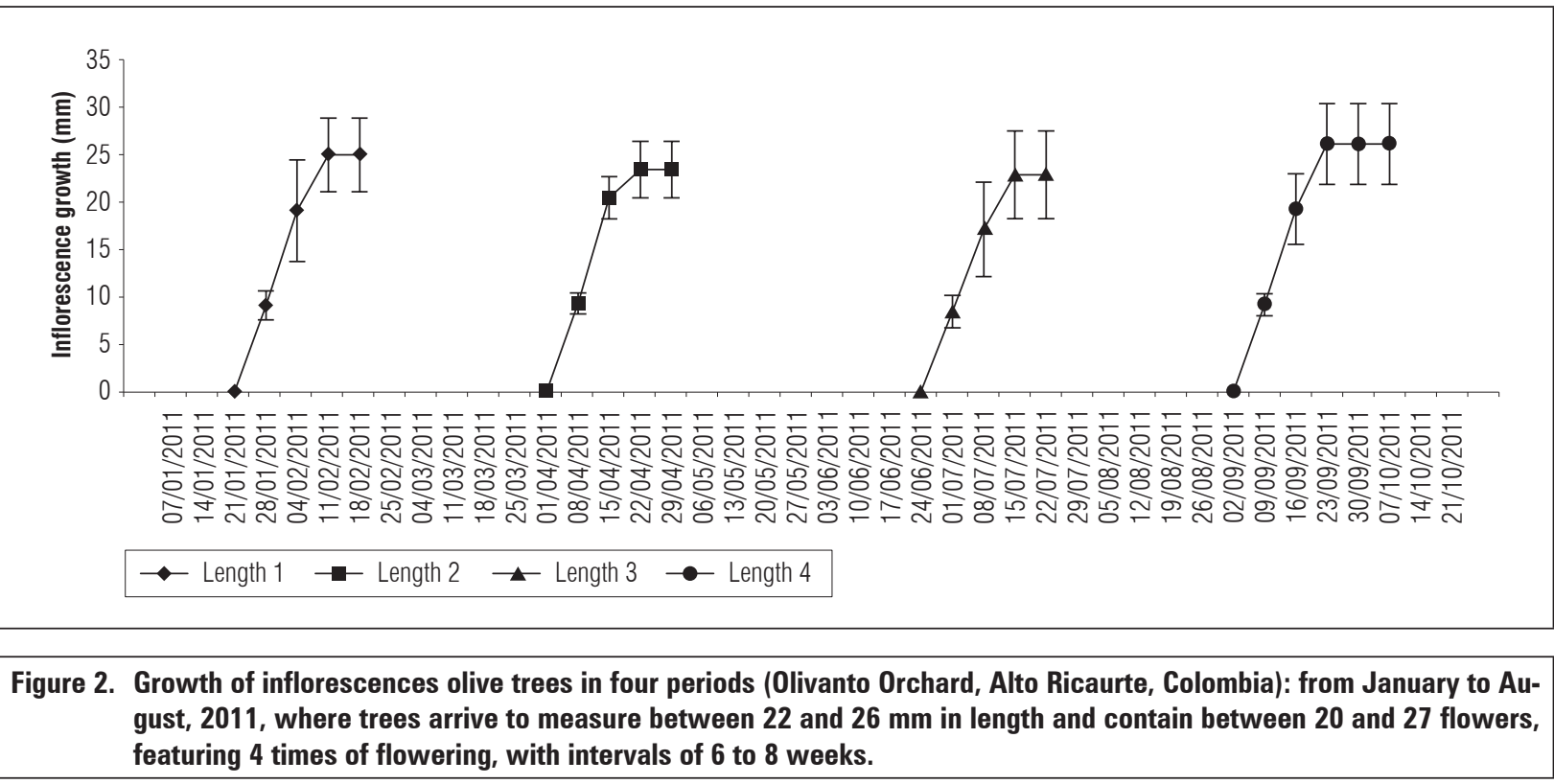

Rev. Colomb. Cienc. Hortic. 


\section{Flower, pollination and fertilization}

The olive tree has perfect and imperfect flowers (Rapoport and Moreno-Alías, 2017); the imperfect ones have a rudimentary or absent ovary; this is a very common phenomenon of morphological sterility, as well as, stamina or masculine gender flowers, which are fruitless (Rapoport, 2014). In the studied region, a lot of perfect and imperfect flowers were observed. For instance, for four periods marked by flowering (Fig. 3): in the first one, there were 26 flowers in inflorescence, from which 11 unfolded petals. The second one had 23 flowers with 10 that opened petals. In the third one, there were found 22 flowers, with 9 that unfolded petals, and, in the last one, there were 13 flowers, where 11 flowers were open. These data allowed us to confirm that the production of inflorescences and flowers in tropical zones has been inconstant because it is influenced by climatic, physiological and genetic factors (Beghe et al., 2015).

The variability and performance of flowers in the inflorescences and the opening capacity did not exceed $50 \%$ (Fig. 3), as compared to those that accomplished growth, pollination and fruit set cycle. Likewise, many of the flowers became parthenocarpic fruits and small drupes with a black color that did not grow because they were affected by the temperature, photoperiod, soil water availability, variety and low supply of pollen (because of the discrepancy of flowering). But inside, they had seeds that fell off 15 to $30 \mathrm{~d}$ after fruit set (Carvajal-Rodríguez and García-Molano, 2017). According to Rojo and Pérez-Badia (2014), when environmental condition are adverse or there is competition between the different organs of the plants, the premature $a b$ scission of fruits or the development parthenocarpic fruits can be induced, which may have occurred in the present study because the trees had water stress in 2009, with rainfall lower than $450.4 \mathrm{~mm}$, IDEAM (2011), which provoked a prolonged vegetative recovery and then vegetative reproduction when plentiful rainfall did occur.

The olive tree needs cross-pollination, with pollen grains spread over $12 \mathrm{~km}$ (Seifi et al., 2015). Additionally, the self-incompatibility pollen-pistil is a feature of the pollination on the flowers. Hence, the flower pistil biochemically recognizes and rejects the pollen that has the same genotype (Rallo and Cuevas, 2017). Also, the olive flower has pollen a day after of another dehiscence and ends up $48 \mathrm{~h}$ later, consequently, the plant has viable pollen until 3 or $4 \mathrm{~d}$ after flowering, making sure that the pollen gets to receptive stigmas (Zhu et al., 2013). Nevertheless, this situation is unknown in the studied region because it has spread only by productive trees, without knowledge on compatibility between pollinating varieties or olive varieties. The duration and viability of pollen has not been identified. In the case of Huerto Olivanto, two varieties were identified; "Picual" and "Azapa", but the variety of other trees is unknown because many of them are not fruitful.

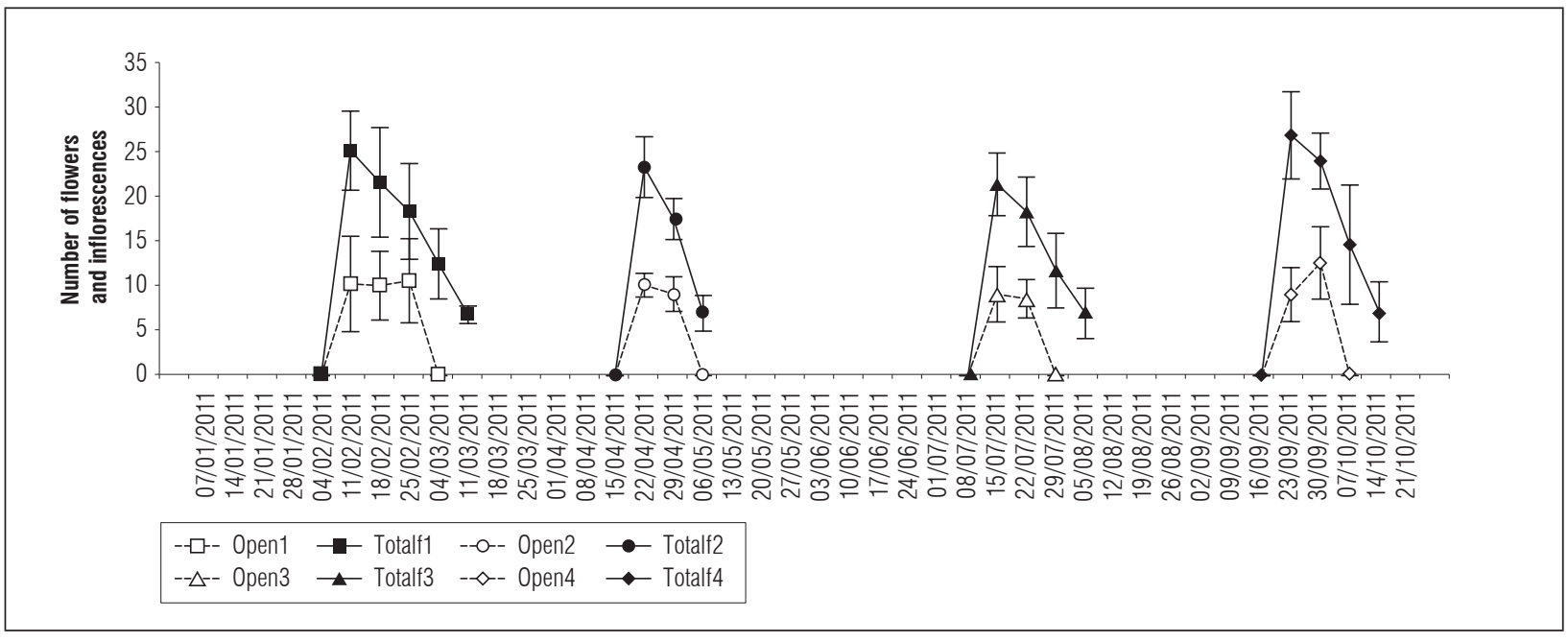

Figure 3. Number of flowers and inflorescences olive trees in four periods (Alto Ricaurte, Colombia). Bloom periods from January to August 2011, with 25, 2-23, 4-21, and 5-27, with a number of open inflorescences of 10, 6-10, 1-9, 14-12, and 6, which do not exceed $50 \%$ germinal. 


\section{Fruit set and fruit growth}

The abscission process of the unfertilized ovaries and some less developed ones is triggered by fruit-setting and the growth principle (Rallo and Cuevas, 2017), and only $2 \%$ of the total flowers are set (Gómez-delCampo and Rapoport, 2008; Rapoport and MorenoAlías, 2017). This process shaped the drupe, which had an endocarp. Then, it started growing since the fertilization and rising size increased during the next 2 months. The mesocarp or fleshy tissue has vacuoles, where it stores the oil (Rapoport and MorenoAlías, 2017). The outer layer or exocarp is strongly welded to the mesocarp. This tissue is composed of the monolayer epidermis with its cuticle (Beltrán et al., 2017) and, depending on maturity, changes color.

In the case of fruits from the Alto Ricaurte region, growth started $8 \mathrm{~d}$ after fruit-set, until weeks 15 and 18. Then, it began a color change. Growth was slow for four weeks approximately. After this, it increased in size for the next 2 or 3 weeks, and finally stopped at the eighth week. Subsequently, the pits began lignifying and growing, and the pulp increased in volume for nearly $30 \mathrm{~d}$. Then, it started changing color, with sigmoidal growth, normal for these types of fruits (Fig. 4).

The performance of the olive trees in the tropics was special because, in the same growing period, the fruiting period may happen two or more times in the same year; consequently, when the tree flourished in two stages, it was observed that the maturity state began a week apart. That means that the harvest of these fruits can be done in the same period. Nonetheless, when 3 or more stages present in the fruiting period, its maturity is seven weeks apart from the second one. Therefore, there were different harvests in the same tree (Fig. 5), unlike regions where the olive is traditionally cultivated because flowering and harvest are concentrated in a single period.

Conversely, Navarro-Ainza and López-Carvajal (2013) confirmed that a temperature above $30^{\circ} \mathrm{C}$ restricts fruit-setting, and Navarro-Ainza et al. (2016) determined that the ideal temperature is $25^{\circ} \mathrm{C}$; in this sense, the temperature in the Alto Ricaurte is on average $27.6^{\circ} \mathrm{C}$, consequently, it stimulates fruitsetting, but the olive varieties in this region are not accurately known.

\section{Summer cessation}

After the pit has become hard, and the fruits have an intense green color and an expected size, they will gradually begin to accumulate reserves until maturity. At first, the fruit will accumulate reserves, such as sugar, and then it will convert them into fatty acids that will form the oil. This process is not directly formed in the fruit; it is produced by the transformation of the sugary reserves. Therefore, maturation is a process that takes place during the autumn, up to winter, in the Mediterranean region (Marcos, 2012; Seifi et al., 2015).

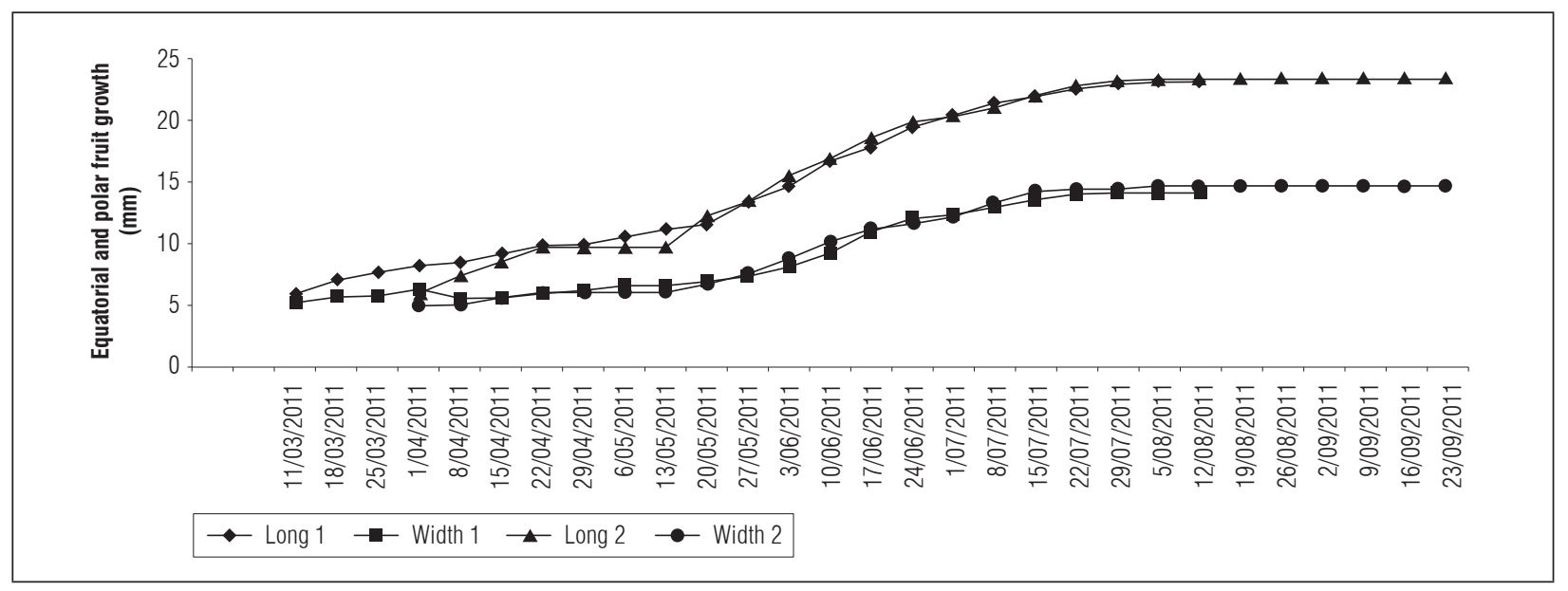

Figure 4. Measurement of equatorial and polar growth of the fruits olive tree, bloom twice between March $11^{\text {th }}$ and April $1^{\text {st }}$ (2011 - Alto Ricaurte, Colombia); growth shows a sigmoidal curve on May $13^{\text {th }}$, which corresponds to the $9^{\text {th }}$ week of the first flowering period and the second 6 Bloom, where the increase in size of the fruits was accelerated. However, maturing for bloom 2 was extended over time. 


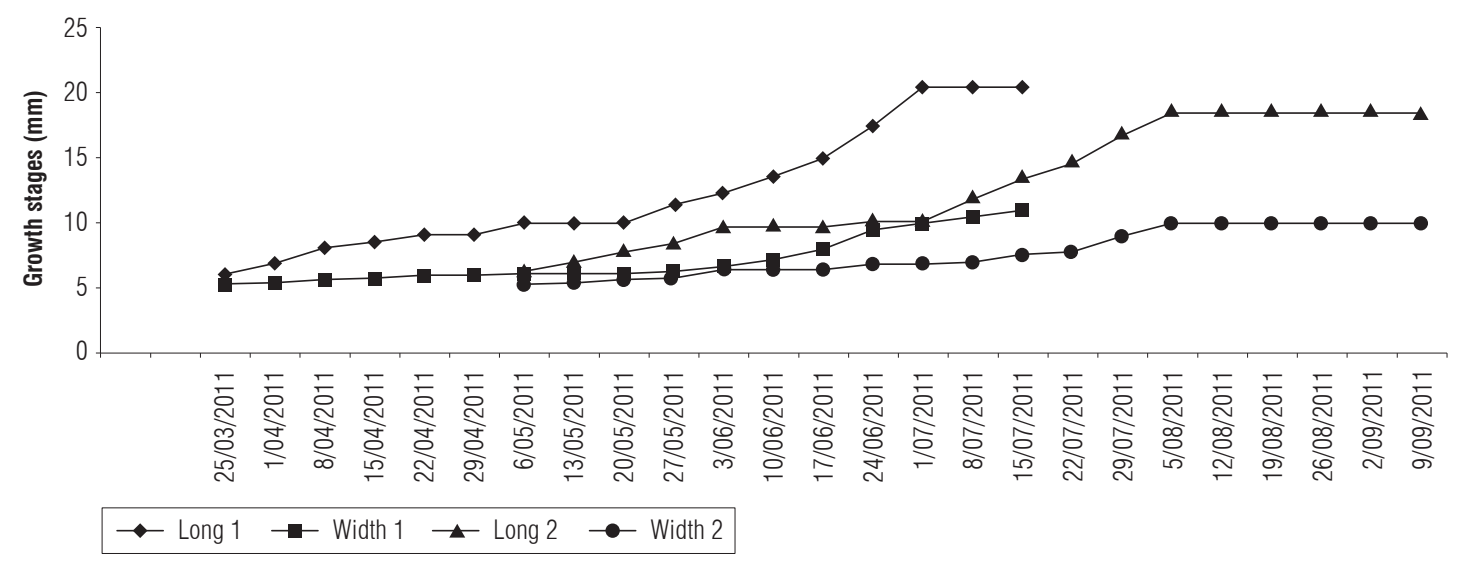

Figure 5. Different stages in the olive tree fruiting in Alto Ricaurte, Colombia. The time that elapsed between the maturing of fruits from the first flowering and the second, with 6 weeks of difference in bloom and a week difference in maturing.

Table 1. Average fatty acids contained in the olive leaves.

\begin{tabular}{|c|c|c|c|c|c|c|c|}
\hline $\begin{array}{c}\text { Age of olive } \\
\text { trees }\end{array}$ & $\begin{array}{c}\text { Methyl } \\
\text { laureate }\end{array}$ & $\begin{array}{c}\text { Methyl } \\
\text { meristato }\end{array}$ & $\begin{array}{c}\text { Methyl } \\
\text { palmitate }\end{array}$ & $\begin{array}{c}\text { Methyl } \\
\text { stearate }\end{array}$ & Methyl oleate & $\begin{array}{c}\text { Methyl } \\
\text { linoleate }\end{array}$ & $\begin{array}{c}\text { Methyl } \\
\text { linolenate }\end{array}$ \\
\hline 4 years & 0.17 & 1.15 & 14.56 & 2.59 & 14.53 & 6.22 & 26.8 \\
\hline$>30$ years & 0.25 & 1.14 & 16.78 & 3.21 & 19.94 & 10.72 & 30.12 \\
\hline
\end{tabular}

It has not been determined whether, in the tropics, there is summer cessation as a result of fructification spreading occurs throughout the year. But, according to physicochemical analysis in the leaves, it was found that the sugars moved by themselves to the fruits, which were sinks, forming fatty acids; this situation can happen throughout the cycle. With the climate conditions in the region, the olive can permanently do photosynthesis; it was observed that, in the leaves of the trees, more fatty acids were synthesized in the 4-year-old trees and trees older than 30 years old (Tab. 1), which may result from a mechanism of the leaves for resisting variable conditions such as temperature, intense solar radiation, and altitude, which is $2200 \mathrm{~m}$.

\section{Phase where the olive changes from green to dark violet}

This is the phase in which olives change their color because of their last maturing process (Jiménez-Herrera et al., 2012). Hence, it is not a sudden process. The olive is green at the beginning, then, it turns yellow as a result of a strong reduction in the content of chlorophyll. Afterwards, the cells start accumulating anthocyanin, and the concentration determines the intensity of the color, from reddish to intense violet and black (Deaquiz-Oyola, 2014; Marcos, 2012). In most crops, the coloring of olives starts in the apex and keeps going until the pendulum. Then, the mesocarp gains color from outside to the violet part until the pit is formed (Beltrán et al., 2017). However, each kind of olive changes its color in a different way; therefore, this phase is where the olive tree variety can be recognized. For instance, some change their color earlier, as many types of 'Manzanilla' olives do, and others do so later, such as the 'Cornicabra' of Toledo. The diversity of color manifestations is so evident that some varieties can be named, such as the Royal variety (red tones) or the 'Veridical', which takes a long time to mature and many times it can be picked while still green (Marcos, 2012).

Some olives turn from green to violaceous precociously, and others keep a predominantly green color even in advanced maturity phases. This feature is affected by the charging of fruits and the watering system. Correspondingly, the color of the oil depends on the color of the olive because part of the chlorophyll remains in the oil. On the contrary, in oil made with olives that have already turned into the color 
expected, the yellow and orange pigments prevail. However, bitter and spicy flavors are characteristics in olive oil from premature harvests (Youssef et al., 2010; Jiménez-Herrera et al., 2012). Therefore, the period in which the olive changes the color matches the end of summer in the Mediterranean (Marcos, 2012).

This phenomenon has not been determined in the Alto Ricaurte region because the flowering and fruiting period are not uniform, which is why a tree may have inflorescences, flowers, green and mature fruits; however, in some years, there was no harvest because of the edapho-climatic conditions, as happened in 2012, 2013, 2014, 2016 and at the beginning of 2016; in this period, the trees physiologically stopped because of low precipitation $(917.7 \mathrm{~mm})$, a result of " $\mathrm{La}$ Niña" phenomenon. That is to say, in those years, the harvest was null, and the flowering fell. In general, in this region, the olives do not have diversity in color; only green (green and violet) and black have been identified in this stage; likewise, when the epicarp is totally or partially black, the fruit can be picked. It would be suitable to highlight that this behavior is proper because there is an average temperature of $27.6^{\circ} \mathrm{C}$, with $13 \mathrm{~h}$ of light in the day.

\section{Maturing}

One of the most important parameters to indicate maturity is color variation, which is related composition (Rallo and Cuevas, 2017). In this stage, there was not only water and oil in the fruits, but also sugars, proteins, pectin, organic acids, tannins, oleuropein and inorganic components; this elements can change according to the crop, weather conditions and, maturity level (Rallo and Cuevas, 2017). Because of the phenology advance in the northwest of Argentina, the synthesis of olive takes place in the summer, when the temperatures are higher; meanwhile, in the Mediterranean, synthesis is carried out in the autumn, when the temperature is moderated; for this reason, changes in the quality of the olive oil and low levels of oleic acid are related to this phenomenon (Searles et al., 2011).

The qualitative components in the olive can be influenced by the environmental conditions of the production year (De La Rosa et al., 2015), in reference to the absolute fatty acids variations and the relation among these individual components, as well as, the relation between the oleic acid and linoleic acid ratio, and the relation among oleic acid and the palmitic and linoleic acids; by the same token, a high temperature may decrease the level of oleic acid, which is connected to an increase in palmitic acid or linoleic acids, which reduce the content of total polyphenols; while, low temperatures increase their content (Beltrán et al., 2017).

Fatty acid components depend on the geographical olive origin and especially the latitude, climate conditions, variety and maturity (Surra et al., 2015). In the Alto Ricaurte region, the temperature was about $27.6^{\circ} \mathrm{C}$ on average (Fig. 1) even though these temperatures were lower than summer temperatures in olive producing regions. Hence, it influenced the organoleptic composition (Tab. 2).

\begin{tabular}{l}
\hline Table 2. Fatty acid content in fruits of the Picual variety \\
compared with the International Olive Council. \\
\begin{tabular}{|l|l|c|c|c|}
\hline \multirow{4}{*}{ Year } & \multicolumn{4}{|c|}{ Fatty acid content in fruits of the Picual variety } \\
\cline { 2 - 5 } & Sample & Palmitic & Oleic & Linoleic \\
\hline \multirow{2}{*}{2012} & Picual of 4 years & 12625 & 74,285 & 0,615 \\
\cline { 2 - 5 } & Picual of 30 years & 13,225 & 71,1 & 0,534 \\
\hline \multirow{2}{*}{2017} & Fresh olives* & 12,97 & 73,0 & 0,865 \\
\cline { 2 - 5 } & Ripe olives** & 13,31 & 72,29 & 0,762 \\
\hline \multirow{4}{*}{} & IOC*** & $7,5-20$ & 55,83 & $3,5-21$ \\
\hline
\end{tabular} \\
* Picual of 10 years \\
** Picual of 30 years \\
*** Parameters International Olive Council (IOC, 2015)
\end{tabular}

\section{Quality of the olive oil}

The composition of the olive oil is determined by variety, edapho-climatic and agronomic conditions in the zone and maturity state of the fruits (Bajoub et al., 2015; Bakhouche et al., 2015). The high fatty acids of olive oil are composed of palmitic, stearic, oleic and linoleic acids (Boskou et al., 2006). Oleate acid is the most important component in olive oil because its quantity is higher; comparing the data of the study area with the IOC, they were within the established range and above that found by Orsavova et al. (2015), which was $66.4 \%$, with the variety being unknown.

Additionally, linolenate acid is found in less quantity in olive oil; for this reason, this acid is part of the polyunsaturated fatty acids, at a proportion of 2.5 to $21 \%$ (IOC, 2015), which the European Economic Community (EEC) also established on November 6 , 2003. This study showed a percentage of 3.79 , which compared with the study performed by Pérez-Arquillué et al. (2003), whose results were $9.46 \%$, showing 
that the results in this study were lower. Meanwhile, the olive oil had a lower quantity of Linolenate acid, where the content must be less or equal to 0.9, but, it is within the range according to the EEC (Tab. 3).

Table 3. Relative percentage composition of Alto Ricaurte olive oil compared to international parameters.

\begin{tabular}{|l|c|c|c|}
\hline \multicolumn{1}{|c|}{ Oil } & 2012 & 2017 & Ranges IOC \\
\hline Myristrate & NR & 0.017012 & $0.00-0.05^{*}$ \\
\hline Palmitate & 14.21 & 13.3697 & $7.50-20.00$ \\
\hline Stearate & 1.668 & 1.06746 & $0.5-5.0$ \\
\hline Oleate & 71.18 & 73.756 & $55-83$ \\
\hline Linoleate & 4.365 & 3.79 & $2.5-21.0$ \\
\hline Linoleate & 0.945 & 0.77073 & $<0 ́ 1.0^{* *}$ \\
\hline
\end{tabular}

${ }^{*}$ Ruiz (2015)

** European Economic Community

Myristic acid is part of the long chain of saturated fatty acids, and its appropriate range, according to Ruiz (2015), is between 0.0 and 0.05 ; the suitable range, according to Jamienson et al. (1927), must be 0.82 . In both cases, the percentage was higher than the figure obtained for the Alto Ricaurte olive oil, which was $0.017 \%$. However, Orsavova et al. (2015) did not report this acid either for analyses carried out in the study area in 2012.

In addition, the concentration of palmitate acid was $13.36 \%$ for the olive oil, which was between the range established by the IOC (2015); however, Sánchez et al. (2003) reported that the content changes depending on the variety. In the case of the Picual variety, the percentage is $11.85 \%$, and the Morisca variety has $14.34 \%$. Since the variety in the study area is Picual, the olive oil would have this acid within the range required by the IOC. For stearate acid, the concentration was $1.06 \%$, within the range reported by Osada (2010), which is $0.5-5.0 \%$ according to the IOC, which, for the tropics, is within range and below that reported by (Pérez-Arquillué et al., 2003), which was $2.10 \%$.

\section{CONCLUSIONS}

The production of table olives or oil in the Alto Ricaurte region is affected by the climatic conditions of the region, which result in photosynthesis throughout the year, which is why the trees do not rest and the olive color changing phase does not stop. Since the precipitation is bimodal, these plants can be fructified twice a year. However, annual rainfall below $1000 \mathrm{~mm}$ causes suspension of physiological activities.

\section{ACKNOWLEDGMENTS}

The authors thank the Fermented Oganic Fertilizers Research Group and the Frutalia Company in Colombia for their expertise and assistance throughout all aspects of our study in Huerto Olivanto.

Conflict of interests: this manuscript was prepared and reviewed with the participation of all authors, who declare that there exists no conflict of interest that puts at risk the validity of the presented results.

\section{BIBLIOGRAPHIC REFERENCES}

Bahloul, N., N. Kechaou, and N.B. Mihoubi. 2014. Comparative investigation of minerals, chlorophylls contents, fatty acid composition and thermal profiles of olive leaves (Olea europea L.) as by-product. Grasas y Aceites 65(3), 035. Doi: 10.3989/gya.0102141

Bajoub, A., A. Carrasco-Pancorbo, E.A. Ajal, N. Ouazzani, and A. Fernández-Gutiérrez. 2015. Potential of LC-MS phenolic profiling combined with multivariate analysis as an approach for the determination of the geographical origin of north Moroccan virgin olive oils. Food Chem. 166, 292-300. Doi: 10.1016/j. foodchem.2014.05.153

Bakhouche, A., J. Lozano-Sánchez, C.A. Ballus, A. Bendini, T. Gallina-Toschi, A. Fernández-Gutiérrez, and A. Segura-Carretero. 2015. A new extraction approach to correct the effect of apparent increase in the secoiridoid content after filtration of virgin olive oil. Talanta 127, 18-25. Doi: 10.1016/j.talanta.2014.03.077

Beghe, D., J. García-Molano, A. Fabbri, and T. Ganino. 2015. Olive biodiversity in Colombia. A molecular study of local germplasm. Sci. Hort. 189, 122-131. Doi: 10.1016/j.scienta.2015.04.003

Beltrán, G., M. Uceda, M. Hermoso, and L. Frías. 2017. Maduración. pp. 187-211. Barranco, D., R. Fernández-Escobar, and L. Rallo (eds.). 2017. El cultivo del olivo. $7^{\text {th }}$ ed. Editorial Mundi-Prensa, Madrid.

Breton, C. and A. Berville. 2013. From the olive flower to the drupe: flower types pollination, self and inter compatibility and fruit set. In: Poljuha, D. and B. Sladonja, (eds.). The mediterranean genetic code - grapevine and olive. IntechOpen, London. Doi: 10.5772/55312

Boskou, D., G. Blekas, and M. Tsimidou. 2006. Olive oil composition. pp. 41-72. In: Boskou, D. (ed.). Olive oil: 
chemistry and technology. $2^{\text {nd }}$ ed. AOCS Monograph Series on Oilseeds. AOCS Press, Champaign, IL.

Bueno, A. and A. Oviedo. 2014. Plantación del olivo. Ediciones INTA, San Juan, Argentina.

Carvajal-R., D. and J. García-Molano. 2017. Determinación del desarrollo floral del olivo (Olea Europaea L.) bajo las condiciones climáticas en el Alto Ricaurte - Sutamarchán- Boyacá. Undergraduate thesis. Fundación Universitaria Juan de Castellanos, Tunja, Colombia.

Carvajal-R. D., S. Tombesi, and M.A. Garcia-Parra. 2018. Evaluation of Corylus avellana L Cvs propagated by rooted suckers and grafting. Rev. Logos Cienc. Tecnol. 10(3), 126-133.

Castillo-Llanque, F. and H.F. Rapoport. 2011. Relationship between reproductive behavior and new shoot development in 5-year-old branches of olive trees (Olea europaea L.). Trees 25(5), 823-832. Doi: 10.1007/ s00468-011-0558-6

Cazanga, R., C. Leiva, A.E. Von Bennewitz, D.X. Quiñones, M.C. Fredes, B.J. Hernández, V.P. Norambuena, T.F. Varas, and G.M. Retamal. 2013. Antecedentes técnicos y económicos para la producción de olivo en la región del Maule. Pub. CIREN 173. Centro de Información de Recursos Naturales, Santiago.

Deaquiz-Oyola, Y. 2014. Los frutos y su fotosíntesis. Conex. Agropecu. 4(1), 39-47.

De La Rosa, P., M. Luna, M. Espeche, and M. Jais. 2015. Composición aceites de oliva del oeste de Catamarca. Rev. APSAL 1(11), http://apsal.org/aceites_de_oliva. php; consulted: december, 2017.

García-Molano, F. 2010. Acercamiento a la olivicultura en Boyacá. Cult. Cient. 8, 8-14.

García-Molano, F. 2012. La biodiversidad del olivo (Olea europea L.) en Colombia: estudio molecular, morfológico y fenológico del germoplasma local. PhD thesis. Università degli Studi di Parma, Parma, Italia.

García-Molano, F. and E. Cheverria. 2014. Comportamiento fenológico del olivo (Olea europaea L.) en el alto Ricaurte (Boyacá). Rev. Logos Cienc. Tecnol. 6(1), 1-17.

García-Molano, F. and S. Jaramillo. 2012. Estudio molecular del germoplasma del olivo en Colombia. Cult. Cient. $10,16-23$.

García-Molano, F., M. Rodríguez, and L. Jaramillo. 2012. Crecimiento de flores y frutos del olivo (Olea europaea L.) Bajo condiciones del trópico. Conex. Agropecu. 2, 15-33.

Gómez del Campo, M., A.M. Morales-Sillero, F. Vita-Serman, M.C. Rousseaux, and P.S. Searles. 2010. El olivar de los valles áridos del Noroeste de Argentina (provincia de Catamarca, La Rioja y San Juan). Olivae (114), 23-45.

Gómez-del-Campo, M. and H. Rapoport. 2008. Descripción de la iniciación floral, floración, cuajado, caída de frutos y endurecimiento del hueso. Agric. Rev. Agropecu. 907, 400-406.

Grijalva, R., R. Macías, A. López, F. Robles, and C. Navarro, 2014. Comportamiento de cultivares de olivo para aceite (Olea europaea L.) bajo condiciones desérticas de Sonora. Rev. Mex. Cienc. Agríc. 5(1), 17-27. Doi: 10.29312/remexca.v5i1.978

IDEAM, Instituto de Hidrología, Meteorología y Estudios Ambientales. 2009. Reportes climatológicos. Bogotá.

IDEAM, Instituto de Hidrología, Meteorología y Estudios Ambientales. 2011. Reportes climatológicos. Bogotá.

IDEAM, Instituto de Hidrología, Meteorología y Estudios Ambientales. 2012. Reportes climatológicos. Bogotá.

IOC, International Olive Council. 2015. Trade standard applying to olive oils and olive pomace oils. COI/T.15/ NC No 3/Rev. 11. Madrid.

Jamienson, G., R. Hann, and W. Baucman. 1927. The chemical composition of Tunisian olive oil. J. Am. Oil Chem. Soc. 4, 63-65. Doi: 10.1007/BF02662908

Jiménez-Herrera, B., A. Rivas, A. Sánchez-Ortiz, M.L. Lorenzo Tovar, M. Ubeda Muñoz, R.M. Callejón, and E. Ortega Bernaldo de Quirós. 2012. Influencia del proceso de maduración del fruto en la calidad sensorial de aceites de oliva virgen de las variedades Picual, Hojiblanca y Picudo. Grasas Aceites 63(4), 403-410. Doi: 10.3989/gya.058212

Kostelos, G. and A. Kiritsakis. 2017. Olive tree history and evolution. pp. 1-12. In: Kiritsakis, A. and F. Shahidi (eds.). Olives and olive oil as functional foods: bioactivity, chemistry and processing. John Wiley \& Sons, Chichester, UK. Doi: 10.1002/9781119135340.ch1

Marcos, D. 2012. El ciclo anual del olivo. Fenología. Reportaje 21. Provedo, Logoño, Spain.

Martínez, M., M. Fuentes, N. Franco, J. Sánchez, and C. de Miguel. 2014. Fatty acid profiles of virgin olive oils from the five olive-growing zones of Extremadura (Spain). J. Am. Oil Chem. Soc. 91(11), 1921-1929. Doi: 10.1007/s11746-014-2528-9

Medina, M. and A. Perdomo. 2015. Criterios para la poda del olivo en canarias. Agrocabildo Cabildo de Tenerife, Santa Cruz de Tenerife, Spain.

Navarro-Ainza, J. and A. Lopez-Carvajal. 2013. Cuajado de frutos y partenocarpia en olivo 'manzanillo' con polinización cruzada. Agron. Mesoam. 24(2), 393-400. Doi: 10.15517/am.v24i2.12539

Navarro-Ainza, J.A.C., A. López-Carvajal, and J.M. Enciso-Lara. 2016. 'Manzanillo' olive (Olea europaea L.) tree response to bioregulators and foliar urea application and its interaction with high temperatures. Rev. Chapingo Ser. Zonas Áridas 15(2), 77-88. Doi: 10.5154/r.rchsza.2016.01.002 
Orsavova, J., L. Misurcova, J. Vavra, R. Vicha and J. Mlcek. 2015. Fatty acids composition of vegetable oils and its contribution to dietary energy intake and dependence of cardiovascular mortality on dietary intake of fatty acids. Int. J. Mol. Sci. 16(6), 12871-12890. Doi: 10.3390/ijms160612871

Osada, J. 2010. Aceite de oliva virgen extra y prevensión de la ateroesclerosis. Academia de Farmacia "Reino de Aragón", Zaragoza, Spain.

Oteros, J., H. García-Mozo, L. Vázquez, A. Mestre, E. Domínguez-Vilches, and C. Galán, 2013. Modelling olive phenological response to weather and topography. Agric. Ecosyst. Environ. 179, 62-68. Doi: 10.1016/j. agee.2013.07.008

Pérez-Arquillué, C., T. Juan, N. Valero, G. Estopañan, A. Ariño, P. Conchello, and A. Herrera. 2003. Estudio de la calidad del aceite de oliva virgen de Aragón. Grasas Aceites 54(2), 151-160. Doi: 10.3989/gya.2003.v54. i2. 258

Pérez, D. 2017. Poda. pp. 519-564. In: Barranco, D., R. Fernández-Escobar, and L. Rallo (eds.). 2017. El cultivo del olivo. $7^{\text {th }}$ ed. Editorial Mundi-Prensa, Madrid.

Rallo, L. and J. Cuevas. 2017 Fructificación y producción. 145-186. In: Barranco, D., R. Fernández-Escobar, and L. Rallo (eds.). 2017. El cultivo del olivo. $7^{\text {th }}$ ed. Editorial Mundi-Prensa, Madrid.

Rapoport, H.F. 2014. The reproductive biology of the olive tree and its relationship to extreme environmental conditions. Acta Hortic. 1057, 41-50. Doi: 10.17660/ ActaHortic.2014.1057.2

Rapoport, H.F. and I. Moreno-Alías. 2017. Botánica y morfología. pp. 35-64. In Barranco, D., R. Fernández-Escobar, and L. Rallo (eds.). 2017. El cultivo del olivo. $7^{\text {th }}$ ed. Editorial Mundi-Prensa, Madrid.

Rojo, J. and R. Pérez-Badia. 2014. Effects of topography and crown-exposure on olive tree phenology. Trees 28(2), 449-459. Doi: 10.1007/s00468-013-0962-1

Ruiz, M. 2015. Técnicas y prácticas de laboratorio para el análisis de aceite de oliva virgen. Cuad. Tecnol. 23. Unión Europea; INTI, Buenos Aires.

Sánchez, J., E. Osorio, A. Montaño, and M. Martínez. 2003. Estudio del contenido en ácidos grasos de aceites monovarietales elaborados a partir de aceitunas producidas en la región extremeña. Gasas Aceites 45(4), 371-377.

Searles, P., M. Agüero, and M. Rousseaux. 2011. El consumo del agua por el cultivo de olivo (Olea europaea L.) en el noroeste de Argentina: una comparación con la Cuenca Mediterránea. Ecol. Austral 21(1), 15-28.
Seifi, E., J. Guerin, B. Kaiser, and M. Sedgley. 2015. Flowering and fruit set in olive: a review. Iran. J. Plant Physiol. 5(2), 1263-1272.

Sotomayor, E. 2002. Fenología del olivo cv Azapa (Olea europaea L.), en el valle de Azapa - Primera Región Tarapaeá, Ariea-Chile. Idesia 2(2), 81-90.

Surra, J., M. Navarro, M. Martínez, and J. Osad. 2015. Aceite de oliva virgen, el alimento con propiedades farmacológicas preventivas de la aterosclerosis. Lucas Mallada (17), 225-245.

Tapia, J. 2012. Análisis de las variables climáticas temperatura, horas frío y dotación de recursos hídricos sobre la producción del cultivo del olivo (Olea europea L.) en el valle de Azapa, comuna de Arica, región Arica y Parinocota. MSc thesis. Tacna Escuela de Posgrado, Universidad Nacional Jorge Basadre Grohmann, Tacna, Perú.

Tonconi, J. 2014. Efectos del cambio climático sobre la producción de aceituna en Yarada, Región Tacna. Idesia 32(2), 29-35. Doi: 10.4067/S0718-34292014000200005

Torres, M., P. Pierantozzi, P. Searles, M.C. Rousseaux, G. García-Inza, A. Miserere, R. Bodoira, C. Contreras, and D. Maestri. 2017. Olive cultivation in the Sourthern Hemisphere: flowering, water requirements and oil quality responses to new crop environment. Font. Plant Sci. 8, 01830. Doi: 10.3389/fpls.2017.01830

Toscano, P., N. Iannotta, and S. Scalercio. 2015. Botanical and agricultural aspects: agronomic techniques and orchard management. pp. 2-74. In: Muzzalupo, I. and S. Micali (eds.). Agricultural and food biotechnology of Olea europaea and stone fruits. Bentham Science Publishers, Sharjah, United Arab Emirates. Doi: 10.2174/97816080599351150101

Trentacoste, E., I. Morenoalías, M. Gómez-Del-Campo, and V. Beyá-Marshall. 2017. Olive floral development in different hedgerow positions and orientations as affected by irradiance. Sci. Hort. 225, 226-234. Doi: 10.1016/j.scienta.2017.06.029

Urbina, V. 2015. El medio ecológico en plantaciones frutales. Monografías de Fruticultura 9. Lleida, Spain.

Youssef, N., W. Zarrouk, A. Carrasco-Pancorbo, Y. Ouni, A. Segura-Carretero, A. Fernández-Gutiérrez, and M. Zarrouk. 2010. Effect of olive ripeness on chemical properties and phenolic composition of chétoui virgin olive oil. J. Sci. Food Agric. 90(2), 199-204. Doi: 10.1002/jsfa.3784

Zhu, W.Z., P. Zhou, J. Xie, G. Zhao, and Z.H. Wei. 2013. Advances in the pollination biology of olive (Olea europaea L.). Acta Ecol. Sin. 33(2), 64-71. Doi: 10.1016/j. chnaes.2013.01.001 